УДК 811.11-112: 81-112.2: 004.942: 159.9

\title{
A MODEL OF THE DIACHRONIC SEMANTIC DIFFERENTIAL: STRATIFICATION OF LEXIS ON FUZZY PRINCIPLES (the case of Older Scots adjectives)
}

\author{
Olena Basalkevych \\ Danylo Halytsky Lviv National Medical University \\ 69, Pekarska St., Lviv, Ukraine, 79000 \\ olena.basalkevych@gmail.com \\ Mykhailo Bilynskyi \\ Ivan Franko National University of Lviv \\ 1, Universytetska St., Lviv, Ukraine, 79000 \\ bislo@ukrpost.ua
}

The steps of a unified mathematical model for the study of synonymy in the context of paradigmatic and epidigmatic associative relationships are revealed in the paper. Joint fuzzy associative fields of two antonyms constitute on the one hand the main component of the associative map activated through fuzzification into a fuzzy associative verbal network, whilst on the other hand it represents a fuzzy modification of the Osgood semantic differential with a diachronic stratification of lexis. The connection of a considerable number of such components based on synonymous adjectives makes an episodical adjectival associative map according to the indicated by Kiss two fundamental relations, with its further activation into a fuzzy adjectival associative network. When it becomes possible to cover all language synonymy we can eventually talk about the Global Fuzzy Semantic Network as an efficient part of Artificial Intelligence.

Keywords: Older Scots, Fuzzy Associative Fields, Fuzzy Associative Word Structure, associative map, Fuzzy Associative Adjectival Network, semantic Osgood's differential, the Fuzzy Normalized Diachronic 8 Interval Semantic Differential, fuzzy stratification, Kiss's associative thesaurus, Global Fuzzy Semantic Network.

\section{Introductory remarks}

The initial focus of the work singled out a collection of synonymic strings of Older Scots qualitative adjectives. The principle of the formation of such historical units involved a comparison of diachronic text prototype dates, the first documented word versions. The main source of the research was DOST (the Dictionary of Older Scots language), available online [11]. For this purpose, the synonyms with older prototypes took earlier places in the sets. The initial principles of the research are provided in [5]. To broaden the study by involving modern approaches and facilities and to reach qualitatively new results, an extension into cognitive or rather associative linguistics was made. The mentioned strings were regarded in the context of associative relations among the fixed Scottish words. We don't mention prototypes here. This reaction to English word-stimuli

(C) O. Basalkevych, M. Bilynskyi, 2017 
based on DOST could be compared with a chain associative experiment of a "historical reaction" $[3 ; 7]$. Although the discussion on associativity of synonyms in the sets is still open [10], we come from a positive opinions of other authors and our own arguments $[3 ; 6]$. The main ones are a deep stylistic-connotative coloration of some of DOST answers and full availability of precedent texts. In historical linguistics these are called diachronic textual prototypes. This type of associativity we call a paradigmatic one. Another kind of this relationship could be found in the associative semantic word structure, indicated for each synonym in the set called epidigmatic associativity. Kiss pointed out these two types of associative relations in his Associative Thesaurus of English [9]. The compilation of this dictionary was based on the undertaken associative experiment. In our case using the stated regularities we are building a net of strings of associated synonyms, well interconnected through the revealed epidigmatic associative relations of any mentioned unit in the string. The received picture is a reconstructed fragmentary associative map of Older Scots adjectives. It represents a mental adjectival lexicon postulated by this evidence for an average Older Scots speaker. The aforesaid constitutes the main premises for the research undertaken in the work.

\section{2. 'Animating' Older Scots lexicon in a fuzzy associative adjectival network 2.1. One-way associative map}

The directionality of the associative map could be speared one-way. Fig. 1 shows a fragment studied in [3]. The general framework of analysis is of interest at this point: vertical strings are the mentioned associative fields of synonyms, horizontal ramification reflects the branches of associative structures of synonymous constituents. All word places are weighted with the coefficients calculated especially for a diachronic case:

$$
W_{i}^{(y)}=\frac{y_{i}-y_{\min }}{y_{\text {max }}-y_{\min }}\left(\frac{1}{n+1}-1\right)+1,
$$

where $\left(y_{\max }-y_{\min }\right)$ is a set range of the time difference between older and younger words in the set, $\left(y_{i}-y_{\min }\right)$ is the time distance from a historical dominant entry to the appearance of an arbitrary word, and $\mathrm{n}$ is the number of words in the string [8]. This formalism was suggested in response to the suggestion of the mathematical linguist Gabriel Altman to assess the dissimilarity measure between synonymous sequencing by the mean value of permutation between the ordinal positions of the same constituent in a synonymous string and its chronological reconstruction.

The mapping principles here are similar with those in Kiss's associative thesaurus, since Kiss declared two main types of connection within his net: between the relevant words reflecting the same or similar concepts in the light of the canonical understanding of synonyms and between the semantic components of a word covering all its senses pertinent to the associative word structure [9].

The neurons construing image-induced networking involves a trace not only of the word form and sense but also of the system containing it. Then the memory of a word includes its usage, relationships, peculiarities of its valency and so on [7].

\subsection{Two-way associative map}

One more strong relation within an associative thesaurus supported by the technique of an associative experiment is that of antonyms (Fig. 2). For our layout we will attribute to this kind of relation the principles of diachronic networking in antonymy. They are the same as those in synonymy.

\subsection{Fuzzification of an associative map}

Basically, fuzzification of the system implies an introduction of membership functions that regulate the level of appropriateness of its components and introduce the degree of belief 


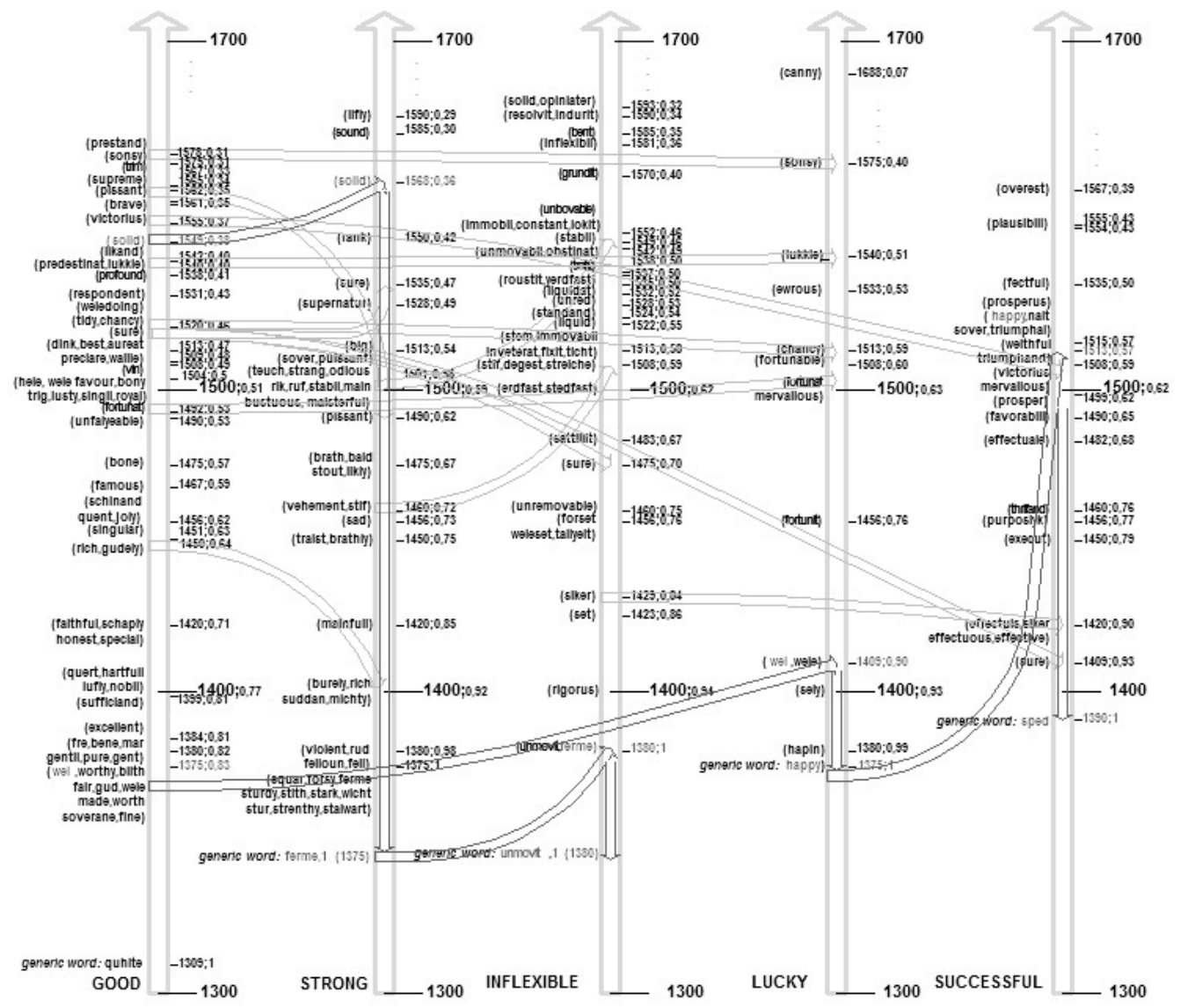

Figure 1. A fragment of a fuzzy associative adjectival network.

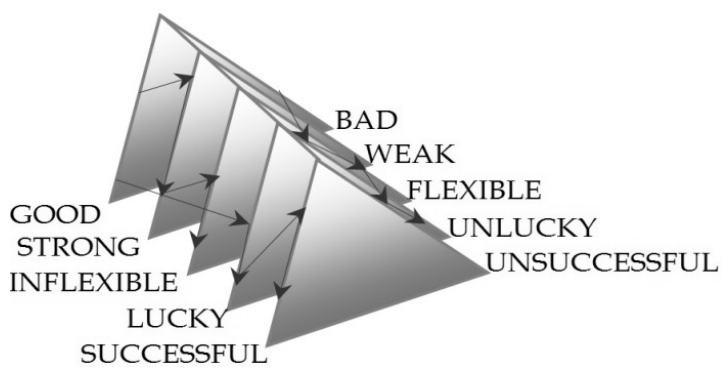

Figure 2. A fragment of a two-way associative map. 
or confidence (trueness) of the made statements. The immediate candidate for this role in our environment is the synonymic weight coefficient introduced above, since it lies within the range $[0 ; 1]$ and depends on the time of a word entry, imparting the earliest words with higher values.

To assimilate the understanding of a weight coefficient to the associativity status and membership function of the map we follow Zipf's law which states that the earliest words are the most frequently used ones [1].

The archaic lexemes mostly stay in the framework owing to their dated documentation.

The words with higher membership functions are more characteristic of the set or better associated with the regarded semantic feature.

Technically, we can indicate two types of fuzzy sub-sets within our network: the fuzzy subset of associated synonyms, which make up the so-called Fuzzy Associative Field (FAF) and the fuzzy sub-set of the word's senses called Fuzzy Associative Word Structures (FAWS).

Applying formula 1 to the dated quotations of the constituents we obtain a descending scale for an arbitrary adjective, e.g. INFLEXIBLE: \{unmovie/1, ferme/1, rigorus $/ 0.94$, set/0.86, siker/0.85; forset $/ 0.76$, set $/ 0.76$, tail3eit $/ 0.76$, unremovable $/ 0.75$, sure $/ 0.75$, sattillit $/ 0.67$, erdfast $/ 0.62$, stedfast $/ 0.62$, stif $/ 0.59$, degest $/ 0.59$, streiche $/ 0.59$, stern $/ 0.58$, immovabil $/ 0.58$, inveterat $/ 0.58$, fixit $/ 0.58$, ticht $/ 0.58$, liquid $/ 0.55$, standand $/ 0.54$, unred $/ 0.53$, liquidat $/ 0.52$, roustit $/ 0.51$, 3erd fast $/ 0.51$, tretit $/ 0.50$, unmovabil/ $/ 0.5$, obstinate $/ 0.5$, stabil $/ 0.49$, immobile $/ 0.46$, constant $/ 0.46$, lokit $/ 0.46$, unbowable $/ 0.46$, grundit/0.4, inflexibil/ $/ 0.36$, bent $/ 0.35$, resolvit $/ 0.34$, indurit $/ 0.34$, solid $/ 0.33$, opiniater $/ 0.33$, limit $/ 0.27$, oken/0.25, knit/0.23, ingrainit/0.2, battit/0.2, sad/0.19, stinted $/ 0.19$, statarie/0.18, heid-set $/ 0.17$, ill-set/0.02\}. Here fuzzification is pretty obvious as the weight factor goes quite low.

The semantic feature or a dominant plays here the role of a linguistic variable, all the indicated subsets' names constitute its term-set: \{Flexible, Inflexible, Brave, Cowardly, Intelligent, Stupid, Large, Small...\}.

In the second sub-set the configured weighted mapping gives us diversely weighted sequences SOLID $\{$ good $/ 0.38$, strong/0.36, inflexible/0.33, loyal/0.03\}; FERME \{strong/1, inflexible/1\}, WEL $\{$ lucky/0.9, happy/0.89, good/0.83\}; HAPPY \{lucky/0.57, successful/0.57\} [2; 3].

Looking at Fig.1 details, membership functions could be found there following the approximate date of any synonym of the sets. By this the main goal of static modeling is met by configuring the weighted fuzzy net demonstrative of the postulated relationships in the lexicon.

\subsection{Activating a fuzzy associative map or network}

On a simulated fuzzy network we can discern the set of places, P, the set of transitions, $\mathrm{T}$, the input function, $\mathrm{I}$, and the output function, $\mathrm{O}$. The input function reflects the transition $t_{j}$ into the set of positions $\mathrm{I}\left(t_{j}\right)$ called the initial positions of a transition release. The output function, $\mathrm{O}$, effects $t_{j}$ into the set of output transition positions $\mathrm{O}\left(t_{j}\right)$. Fuzziness is represented in the set of places, $\mathrm{P}$, taken by words with appropriate membership functions. The release of a transition rearranges the fuzziness distribution of the route, and the output place-word according to the rule $\mu\left(\mathrm{x}_{1} \cap \mathrm{x}_{2}\right)=\min \left[\mu\left(\mathrm{x}_{1}\right), \mu\left(\mathrm{x}_{2}\right)\right]$ gains the minimum value of membership functions of the input positions. The fruit of this animation is in the probing of the n-step environment of any word within the net, a technique also introduced by Kiss. According to the FAWS of the regarded word, the transition to the most significant (with a maximum membership function) output position of another associative field will be released. The following transition will be made within the reached field to its dominant. For the dominant we repeat the same algorithm. At the $2 \mathrm{n}$-th step we will reach n-associations to the studied stimulus because two transitions normally lead to any new association: the between-field one and the inside-field one. The performance of the constructed Fuzzy Associative Adjectival Network is oriented at the maximum belief (maximum membership 
function) but still sensitive to the weakest link of the route. By this we have realized the $2 n$-step environment of only one wing. The other $2 \mathrm{n}$ steps should be applied to the time-antonym of the studied stimulus. Shuffling the order, the transition to a dominant is realized immediately, since the gravity to the main bearer of the meaning triggers here. The notion of time-based antonymy will be considered in the following section. An example of the animation will be provided in the discussion part.

\section{Procedure of the Research \\ 3.1. A fuzzy diachronic differential}

Of interest here for our examples of network modeling are the sections of Fig. 2, the triangles with joint antonymic sets of synonyms or the so-called lexical semantic bipolar fields. Fig. 3 shows this for the STRONG-WEAK dichotomy in Older Scotts [4]. All the meaning subtleties are introduced for both concepts along the triangle sides. Since in our interpenetration we deal with two fuzzy sets all meaning shades are estimated by appropriate membership functions. Therefore under another angle we can see here a modification of Osgood's semantic differential on fuzzy principles. It is rather chaotic with altering intervals but, luckily, it reflects an amazing number of meaning subtleties. We will call it a natural diachronic semantic differential on fuzzy principles. The following logical step should be normalization through its division into equal 100 year intervals from the Older Scots period. Only sectional or adjacent subtleties with their membership functions will be estimated. This tool will be named the Fuzzy Normalized Diachronic 8-Interval Semantic Differential (FND8ISD).

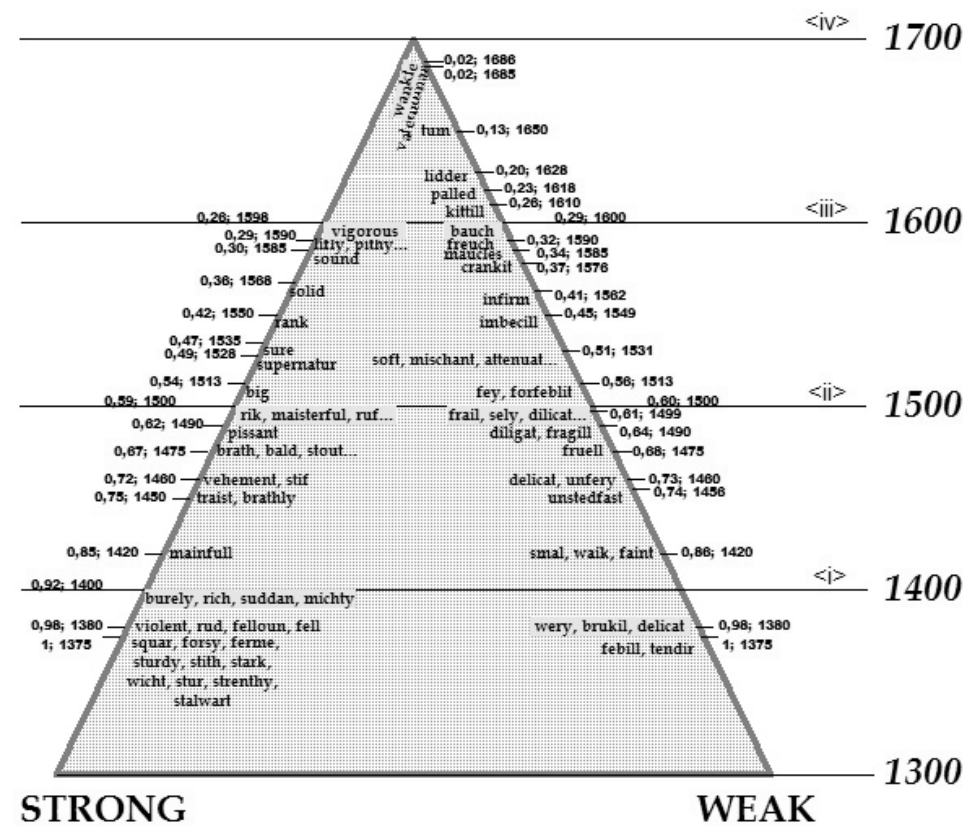

Figure 3. The natural and fuzzily normalized diachronic 8-interval semantic differential. 
The shown in Fig. 2 dichotomy represents the cross-cultural potency-measuring differential Strong-Weak in the Older Scots performance. This kind of reconstruction is of sheer historical interest since scarcely anyone is going to design such experiment on objects evaluation in Older Scots.

\subsection{Lexis stratification on fuzzy principles.}

The following concerns the natural equality of intervals for both sleeves and an appropriate structure for a stratification device. The tenets of a fuzzy stratification, originate from the latest recommendations of Lotfi Zadeh, the farther of Fuzzy Logic. In our particular case stratification seems a little unusual since we talk about strata combining the opposite flanks of the differential. It could be called a fuzzy stratification of lexical oppositions. Under a more thorough consideration it can bring some interesting fruit too. Possibilities of ascertaining the lexis stratum gravity poles, time-focused antonymy and significance status of the strata follow from the manipulation with border membership functions [4]. In particular, introducing a fuzzy variable of gravity for the flanks, i.e. (strong $/ \mu_{1}(\mathrm{x})$; weak $/ \mu_{2}(\mathrm{x})$ ), for any stratum, where $\mu_{1}(\mathrm{x})$ and $\mu_{2}(\mathrm{x})$ are the membership functions of each sectional antonymic pair, we will estimate which concept prevails at that moment as well as the intensity distribution of positive and negative concepts development. The 'precise time' antonymy could be analyzed for section pairs at any moment within any stratum by a straight bridging of the two flanks. The notions of the core and periphery of a fuzzy set will help us analyze the significance of a concrete stratum or ignore less important strata with specific fuzziness for any concept, if required. The available illustration follows in the discussion part.

\section{Discussion \\ 4.1. $N$-associations trees}

Even the best theory weighs by its practical issues or a reasonable contribution to the state of affairs. The reconstruction of the Older Scots associative map or mental lexicon in its turn weighs by its animation and reproduction in the sphere of plausible diachronic Natural Language Processing (NLP). The association chains presumably got formed in the mind of the ancient speaker with some degree of belief. Historical linguistics can appropriate this technique for its further searches and clarifications.

According to the algorithm described above, in Fig. 1 two inferred associations on the given language fragment are reflected by bold arrows. Let us consider one of them. From the place (SOLID/0.38) of the field GOOD following the maximum significance of FAWS branches for SOLID we release a transition to the place (SOLID/0.36) within the field STRONG gaining the membership function 0.36 that is the minimum of the previous ones. With the given fuzziness we transfer within the field STRONG to its historical and frequent dominant (FERME/1), reaching the first association with the minimum route membership function 0.36 . Following the FAWS for FERME we go to the following most significant place (FERME/1) within the field INFLEXIBLE. Assessing its membership function, it is evident that we deal with one of the dominants. So by this we can finish our association chain since no other value is registered in the WAFS for FERME.

The opposite antonymic association chain is produced by the transfer to the 'nearest time' antonym for (SOLID/0.38) dated by 1549 within GOOD, that is (LIDDER/0.43) dated by 1550 within $\mathrm{BAD}$, the gained by this membership function evidently makes 0.38 . After following the agreed algorithm alteration we make the inner transition within BAD to its historical and frequent dominant (WIKIT/1) with the same minimum belief degree 0.38 , following WIKIT'S FAWS the following transition will be to (WIKIT/1) within the field INCOMPETENT, the dominant of the field. Therefore we trace the FAWS of WIKIT again, transferring to (WIKIT/0.59) within the 
field DANGEROUS with the membership function 0,38 . The following transition is made to the dominant of DANGEROUS, the place (PERILOUS/1), with the minimum route membership function 0.38 , thus exhausting possible associations since no other value is registered within the FAWS of PERILOUS for the regarded language fragment.

The arrived conclusion is that for the stimulus SOLID in the Older Scot brings out a slight positive association (the belief degree 0.36) with FERME and just a little bit stronger negative association chain LIDDER-WIKIT-PERILOUS (the belief degree 0.38 ). The construed association tree is as follows:

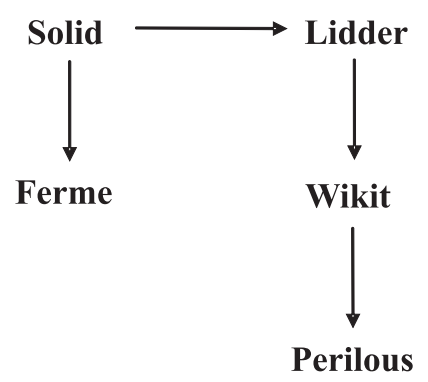

Figure 4. Associative two-branch chain for SOLID

On the basis of the observable evidence it could be inferred that Older Scots, same as probably other old languages, reveal a higher branching of the negative flank of Osgood's scale. The validness of the figure is dubious with the final belief degree $0.36=\min (0.38 ; 0.36)$. But still it has its logical and historical place.

\subsection{Fuzzy differential application}

The application of a semantic differential of Osgood is aimed at evaluation of both personal characteristics of a respondent and the studied opinions, attitudes and values on a psychometrically controlled scale.

When the former is a subject of a modern psycholinguistics, the Older Scots potencies are evidently not of merit, as was said before. However if we talk about a new kind of reconstruction, this time of a psychological and descriptive system of Older Scots authors as main representatives of that day's population, it may reveal stronger possibilities.

Historical lexical studies could be performed through the analysis of the available DOST citations. The potencies are humble but tangible. In the case of a psycholinguistic portrait of a Scottish penman we can collect quotations for the whole period or for some temporal section, of all authors for a collective picture or for any chosen one(s). The upgrading of the differential figure should be done for the research of one author's opinions or for a particular time moment within the lapse from 1100 till 1700 . The triangle will be cut and turned into a trapezium which could still play the expected differentiation role on condition of treating the upper line as a neutral connector of the flanks. In the case of a study throughout the whole period, the observations are expected to be statistically more valid.

Since in the present paper this aspect of research is only lateral we will confine ourselves to the determining the network properties of the studied adjectives in combination with the nouns in the DOST textual prototypes from the texts of Scottish authors spanning the period. To these ends we used the 
Fuzzy Normalized Diachronic 8-Interval Semantic Differential (FND8ISD) providing an interval of MF (membership function) values (Table 1) which could be demonstrative of a fragment of the mental thesaurus within the given field of adjectives at the time.

Table 1

A fragment of the tabulated FND8ISD report where MF stands for membership function and FND8ISD does for fuzzy normalized diachronic 8-interval semantic differential.

\begin{tabular}{|c|c|c|c|c|c|}
\hline Year & MF & \begin{tabular}{|l|} 
N8ISD \\
Estimator
\end{tabular} & Collocation & Title & Author \\
\hline 1 & 2 & 3 & 4 & 5 & 6 \\
\hline 1300 & --- & --- & --- & --- & --- \\
\hline \multirow[t]{4}{*}{1400} & \multirow[t]{4}{*}{0.917} & Burely & $\begin{array}{l}\text { commowns had gret ferly Of sa } \\
\text { buyrly [v.r. burly] a companye }\end{array}$ & $\begin{array}{l}\text { Die Fragmente des } \\
\text { Trojankrieges }\end{array}$ & Barbour, John \\
\hline & & Rich & A fare cite, baith ryche $\&$ witht & $\begin{array}{l}\text { The Buik of } \\
\text { Alexander, ... }\end{array}$ & \\
\hline & & Suddan & $\begin{array}{l}\text { Thelogonius ... gaif him sic a } \\
\text { sodane [L. sic potenter] dusche ... } \\
\text { on the nek ... That he his crage straik } \\
\text { ewyn in two }\end{array}$ & $\begin{array}{l}\text { Die Fragmente des } \\
\text { Trojankrieges }\end{array}$ & Barbour, John \\
\hline & & Michty & He was michty and staluart to stand & $\begin{array}{l}\text { The Buik of } \\
\text { Alexander, ... }\end{array}$ & \\
\hline \multirow[t]{9}{*}{1500} & \multirow[t]{9}{*}{0.586} & Rik & $\begin{array}{l}\text { Richt as the rose ... In ruby colour } \\
\text { reid most ryik of hew }\end{array}$ & $\begin{array}{l}\text { King Hart. In The } \\
\text { Maitland Folio } \\
\text { Manuscript I lxxxvii } \\
\end{array}$ & Craigie, W.A. \\
\hline & & Odious & $\begin{array}{l}\text { He hatit women sa odious That he } \\
\text { wald neuer ly with nane }\end{array}$ & $\begin{array}{l}\text { The Buke of the } \\
\text { Sevyne Sagis }\end{array}$ & $\begin{array}{l}\text { Rolland, John of } \\
\text { Dalkeith }\end{array}$ \\
\hline & & Maisterful & $\begin{array}{l}\text { I haue na myster to matche with } \\
\text { maisterfull men }\end{array}$ & $\begin{array}{l}\text { The Taill of Rauf } \\
\text { Coilzear }\end{array}$ & \\
\hline & & Ruf & $\begin{array}{l}\text { Ane ryall rufe het fyre war my } \\
\text { desyre }\end{array}$ & $\begin{array}{l}\text { The Taill of Rauf } \\
\text { Coilzear }\end{array}$ & \\
\hline & & Stabil & $\begin{array}{l}\text { Farand on thair stedis, stout men and } \\
\text { stabill }\end{array}$ & $\begin{array}{l}\text { The Knightly Tale } \\
\text { of Golagros and } \\
\text { Gawane }\end{array}$ & $\begin{array}{l}\text { Stevenson, } \\
\text { George (ed.) }\end{array}$ \\
\hline & & Bustuous & $\begin{array}{l}\text { A boustous bowe within his honde } \\
\text { he bor; }\end{array}$ & $\begin{array}{l}\text { The Poems of Robert } \\
\text { Henryson }\end{array}$ & $\begin{array}{l}\text { Henryson, } \\
\text { Robert }\end{array}$ \\
\hline & & Teuch & $\begin{array}{l}\text { Sic ane stubill husband man wald } \\
\text { stryke stoutly; Thair is mony toun } \\
\text { man to tuggill is full teuch }\end{array}$ & $\begin{array}{l}\text { The Taill of Rauf } \\
\text { Coilzear }\end{array}$ & \\
\hline & & Main & $\begin{array}{l}\text { With fyre of tunder Ane gret mane } \\
\text { fyre thai maide thair wndere }\end{array}$ & $\begin{array}{l}\text { The Buke of the } \\
\text { Sevyne Sagis }\end{array}$ & $\begin{array}{l}\text { The Buke of the } \\
\text { Sevyne Sagis }\end{array}$ \\
\hline & & Strang & $\begin{array}{l}\text { With vesage lufly and lang, Body } \\
\text { stalwart and strang }\end{array}$ & $\begin{array}{l}\text { The Knightly Tale } \\
\text { of Golagros and } \\
\text { Gawane }\end{array}$ & $\begin{array}{l}\text { Stevenson, } \\
\text { George (ed.) }\end{array}$ \\
\hline 1600 & 0.255 & Proud & $\begin{array}{l}\text { The watteris, fluidis, proud and } \\
\text { suallein, that with thair force caries } \\
\text { with them euerie thing }\end{array}$ & $\begin{array}{l}\text { The Bannatyne } \\
\text { Miscellany }\end{array}$ & $\begin{array}{l}\text { Scott, Sir } \\
\text { Walter, } \\
\text { Laing, D. and } \\
\text { Thomson, T. } \\
\text { (eds.) }\end{array}$ \\
\hline
\end{tabular}


End Table 1

\begin{tabular}{|c|c|c|c|c|c|}
\hline 1 & 2 & 3 & 4 & 5 & 6 \\
\hline 1700 & --- & --- & --- & --- & --- \\
\hline \begin{tabular}{|l}
1700 \\
$/ 1686$
\end{tabular} & 0.019 & Wankle & $\begin{array}{l}\text { Your wankle leggs canno support ye } \\
\text { Sae sit ye down, till I exhort ye }\end{array}$ & \begin{tabular}{|l|} 
A Joco-Serious \\
Discourse ...
\end{tabular} & $\begin{array}{l}\text { Stuart, George.; } \\
\text { B. Tooke }\end{array}$ \\
\hline 1600 & 0.290 & Bauch & $\begin{array}{l}\text { He fand me bauche in the Latin } \\
\text { toung; }\end{array}$ & $\begin{array}{l}\text { The Autobiography } \\
\text { and Diary of Mr. } \\
\text { James Melvill, ... }\end{array}$ & $\begin{array}{l}\text { Melville, James, } \\
\text { Pitcairn, Robert }\end{array}$ \\
\hline \multirow[t]{7}{*}{1500} & \multirow[t]{7}{*}{0.606} & Frail & $\begin{array}{l}\text { Gude faith is flemyt, worthin fraellar } \\
\text { than glas }\end{array}$ & $\begin{array}{l}\text { The Poems of Robert } \\
\text { Henryson }\end{array}$ & $\begin{array}{l}\text { Henryson, } \\
\text { Robert }\end{array}$ \\
\hline & & Sely & $\begin{array}{l}\text { Na, schir, considder my } \\
\text { complexioun, Selie and [Bann. And } \\
\text { seikly] waik and off my nature tender }\end{array}$ & $\begin{array}{l}\text { The Poems of Robert } \\
\text { Henryson }\end{array}$ & $\begin{array}{l}\text { Henryson, } \\
\text { Robert }\end{array}$ \\
\hline & & Dilicat & Aboundance of dilicat meits & $\begin{array}{l}\text { Clariodus; a Metrical } \\
\text { Romance }\end{array}$ & Irving, D. (ed.) \\
\hline & & Decrepit & (ane ald man and decrepit) & \begin{tabular}{|l|} 
The Poems of Robert \\
Henryson
\end{tabular} & \begin{tabular}{|l|}
$\begin{array}{l}\text { Henryson, } \\
\text { Robert }\end{array}$ \\
\end{tabular} \\
\hline & & Unsmart & $\begin{array}{l}\text { Forther mair, ane bow that is ay bent } \\
\text { Worthis vnsmart }\end{array}$ & $\begin{array}{l}\text { The Poems of Robert } \\
\text { Henryson }\end{array}$ & $\begin{array}{l}\text { Henryson, } \\
\text { Robert }\end{array}$ \\
\hline & & Warsh & $\begin{array}{l}\text { Erudices ... Rycht warsch [A. } \\
\text { warsche] and wan and walowit as } \\
\text { the wede }\end{array}$ & $\begin{array}{l}\text { The Poems of Robert } \\
\text { Henryson }\end{array}$ & $\begin{array}{l}\text { Henryson, } \\
\text { Robert }\end{array}$ \\
\hline & & Frevoll & $\begin{array}{l}\text { Gud fayth is flemit, worthin } \\
\text { frewollar than glas }\end{array}$ & \begin{tabular}{|l|} 
The Poems of Robert \\
Henryson
\end{tabular} & \begin{tabular}{|l|} 
Henryson, \\
Robert
\end{tabular} \\
\hline \multirow[t]{3}{*}{$\begin{array}{l}1400 \\
/ 1380\end{array}$} & \multirow[t]{3}{*}{0.984} & Wery & $\begin{array}{l}\text { Zozimas, Thocht he auld \& very } \\
\text { vas, zarnand for to se th[at] sycht ... } \\
\text { folouyt fast vith al his mycht; }\end{array}$ & $\begin{array}{l}\text { Legends of the } \\
\text { Saints. }\end{array}$ & Barbour, John \\
\hline & & Brukill & $\begin{array}{l}\text { Thadee, that licht woman wes \& } \\
\text { richt brukil of hyre flesche; }\end{array}$ & $\begin{array}{l}\text { Legends of the } \\
\text { Saints. }\end{array}$ & Barbour, John \\
\hline & & Delicat & $\begin{array}{l}\text { This Adryane wes of gret state, \& } \\
\text { 3ung, faire, and delycat; }\end{array}$ & $\begin{array}{l}\text { Legends of the } \\
\text { Saints. }\end{array}$ & Barbour, John \\
\hline 1300 & |--- & |--- & |--- & \begin{tabular}{|l|}
--- \\
\end{tabular} & --- \\
\hline
\end{tabular}

The inferring comment is that in the mind of the mentioned compiled Scottish speaker:

Companye could be buyrly with the degree of belief 0.917 .

Women could be odious with the degree of belief $\mathbf{0 . 5 8 6}$

Watteris, fluidis could be proud with the degree of belief $\mathbf{0 . 2 5 5}$

Leggs could be wankle with the degree of belief $\mathbf{0 . 0 1 9}$

Me could be bauche with the degree of belief $\mathbf{0 . 2 9 0}$

Complexioun could be selie with the degree of belief $\mathbf{0 . 6 0 6}$

Woman could be brukil with the degree of belief $\mathbf{0 . 9 8 4}$

The fuzziness of the co-occurring words spreads for the whole range of collocations in syntagmatic associations. It is supported in paradigmatic and epidigmatic cases. It provides us with a possibility of completing the analysis by adding this kind of relation. The following step could be the enrichment of an associative map with the syntagmatic noun-combining associations of the adjectives studied. 


\subsection{Stratification notes}

The mentioned specificity of a differential is the sameness of intervals for the two flanks of the corresponding section of our network. Its figure represents the time stratification of lexical oppositions. Manipulating with the membership functions, the issues become drawn with a certain degree of belief. The first of them, time antonymy reveals itself at the opposite ends of stratification lines. Contrasting data from table 1 we can obtain time oppositions for interval limits. Sometimes several words refer to the indicated time points, since the characterized membership function remains the same; without hesitation we can choose one arbitrary representative for a flank. In some cases the time error for adjacent words within the studied stratum could be adopted, this time it should be no more than 50 years. Then the contrasted pairs are

1400, (Burely/0.917) - 1380, (Wery/0.984)

1500, (Rik/0.586) - 1500, (Frail/0.606)

1600, $($ Proud/0.255) - 1600, (Bauch/0.290)

and for the taken error in 1700 the time opposition is missing. (Table 1, Fig. 3)

Now adapting the fuzzy variable gravity: $=\left(\mathrm{STRONG} / \mu_{1}(\mathrm{x}) ; \mathrm{WEAK} / \mu_{2}(\mathrm{x})\right)$ for any of them as the stratum upper borders, we will characterize the layers underneath:

for $1300-1400$ stratum gravity $=(\mathrm{STRONG} / 0.917$; WEAK/0.984 $)$

for $1400-1500$ stratum gravity $=(\mathrm{STRONG} / 0.586 ; \mathrm{WEAK} / 0.606)$

for $1500-1600$ stratum gravity $=($ STRONG/0.255; WEAK/0.290 $)$.

The gravity provides arguments in favour of the WEAK concept for all stratums. So the Ostgood negative differential which is typical of a more exciting concept, becomes the pole for the whole stratification structure.

For a more superficial analysis less meaningful, peripheral areas sometimes are cancelled; in the case of fuzzy logic, this limit is defined by the negligible value of a membership function. Let us adopt 0.25 as the fuzzy measure separating the field core from the periphery. Analyzing this level for both flanks we cut the last 1600-1700 stratum as too weak a representative, which is supported by the previous survey where both the opposition and the gravity variable are not regarded for the level.

\section{Concluding remarks}

The line of several interesting reconstructions of Older Scots adjectival fields correlation has been suggested in the work. Fuzzy Associative Adjectival Network or animated Older Scottish lexicon with the release of $n$-associations two branch chains, natural and Normalized Diachronic 8-Interval Semantic Differentials with the potency to see some Scottish concepts in all possible subtleties through the eyes of Older Scottish writers and fuzzy stratification of Older Scots adjectival oppositions considering time synonymy, positive and negative concept development, and the core-oriented research of semantic fields are the main ones of them. Their role in historical linguistics is new and could be studied and solidified in further research endeavours. The purpose of this evolution model is to reaffirm and broaden the implementation of Fuzzy Logic with its great apparatus for studying the real vagueness of natural language phenomena in simulated diachronic NLP with its unpredictable and border-breaking potencies.

\section{Список використаної літератури}

1. Арапов М. В. Математические методы в исторической лингвистике / М. В. Арапов, М. М. Херц. - М. : Издательство "Наука", 1974. - 165 с.

2. Басалкевич О. Є. Діахронна модель творення прикметникових синонімічних рядів у давньошотландській мові / О. Є. Басалкевич // IX Міжнародна науково-практична конференція 
“Мова-Культура-Особистість". - Наукові записки національного університету “Острозька Академія". - Острог, 2015. - № 54. - С. 91-97.

3. Басалкевич О. С. Нечітке моделювання асоціативних карт // IV Міжнародна науково- практична заочна конференція “Лінгвокогнітивні та соціокультурні аспекти комунікаціі”. - Наукові записки національного університету “Острозька Академія”. - Острог, 2015. - № 56. - С. 33-38.

4. Басалкевич О. С. Нечіткий діахронний диференціатор / О. С. Басалкевич // Збірник матеріалів IV українсько-німецької конференції “Інформатика. Культура. Техніка”. - Одеса, 30 червня - 2 липня, 2016. - С. 106-108.

5. Білинський М. Е., Басалкевич О. Є. Діахронні дослідження синонімії з використанням реляційної бази даних / М. Е. Білинський, О. С. Басалкевич // Комп’ютерні науки та інформаційні технології. Вісник НУ “Львівська Політехніка”. - № 710 - 2011. - С. 204-208.

6. Пашковська Н. Ф. Синонімія як засіб відтворення національної ментальності / Н. Ф. Пашковська // Наукове видання “Мова і культура". - Випуск 11. Том XII (124). - Київ : Видавничий дім Дмитра Бураго. - С. 126.

7. Селіванова О. О. Сучасна лінгвістика. Напрями та проблеми / О. О. Селіванова - Полтава : Довкілля-К, 2008. - $711 \mathrm{c.}$

8. Bilynskyi M. Synonymous string as a diachronic reconstruction: The OED Middle English Evidence for verbs and deverbal coinages / M. Bilynskyi // Inozemna Philologia. - Lviv, 2009. - Issue 121. - P. 20-43.

9. Kiss G. R. An associative thesaurus of English and its computer analysis / G. R. Kiss., C. Armstrong, R. Milroy, J. Piper // The Computer and Literary Studies / Aitken A., Bailey R. W. and HamiltonSmith N. (Eds.). - Edinburgh : University Press. - 1973. - 315 p.

10. Mochida A. Antonymy and Synonymy in Adjectives in L2 Mental Lexicon: Associative or Conceptual relations? [Електронний ресурс] // The University of Queensland, 2003. - www. geocities.jp/akiramochida33/researchpro.html

11. The Dictionary of the Scots Language. [Електронний ресурс] / Caroline Macafee A History of Scots to 1700 // Edinburgh: Scottish Language Dictionaries, 2007. - www.dsl.ac.uk

\section{References}

1. Arapov M. V. Matematicheskie metody v istoricheskoy lingvistike / M. V. Arapov, M. M. Herts. - M. : Izdatelstvo "Nauka", 1974. - 165 s.

2. Basalkevych O. Ye. Diakhronna model tvorennia prykmetnykovykh synonimichnykh riadiv u davnoshotlandskii movi // IX Mizhnarodna naukovo-praktychna konferentsiia "Mova-KulturaOsobystist". - Naukovi zapysky natsionalnoho universytetu "Ostrozka Akademiia". - Ostroh, 2015. - № 54. - S. 91-97.

3. Basalkevych O. Ye. Nechitke modeliuvannia asotsiatyvnykh kart// IV Mizhnarodna naukovo-praktychna zaochna konferentsiia "Linhvokohnityvni ta sotsiokulturni aspekty komunikatsii". - Naukovi zapysky natsionalnoho universytetu “Ostrozka Akademiia”. - Ostroh, 2015. - № 56. - S. 33-38.

4. Basalkevych O. Ye. Nechitkyi diakhronnyi dyferentsiator // Zbirnyk materialiv IV ukrainskonimetskoi konferentsii "Informatyka. Kultura. Tekhnika". - Odesa, 30 chervnia - 2 lypnia, 2016. - C. 106-108.

5. Bilynskyi M. E., Basalkevych O. Ye. Diakhronni doslidzhennia synonimii z vykorystanniam reliatsiinoi bazy danykh // Kompiuterni nauky ta informatsiini tekhnolohii. Visnyk NU "Lvivska Politekhnika”, № 710 - 2011. - S. 204-208.

6. Pashkovska N. F. Synonimiia yak zasib vidtvorennia natsionalnoi mentalnosti. Naukove vydannia "Mova i kultura" Vypusk 11. Tom XII (124). - Kyivskyi natsionalnyi universytet imeni Tarasa Shevchenka, Vydavnychyi dim Dmytra Buraho. - C. 126.

7. Selivanova O. O. Suchasna linhvistyka. Napriamy ta problemy / O. O. Selivanova - Poltava : Dovkillia-K, 2008. - $711 \mathrm{~s}$. 
8. Bilynskyi M. Synonymous string as a diachronic reconstruction: The OED Middle English Evidence for verbs and deverbal coinages / M. Bilynskyi // Inozemna Philologia. - Lviv, 2009. - Issue.121. - P. 20- 43.

9. Kiss G. R. An associative thesaurus of English and its computer analysis / G. R. Kiss, C. Armstrong, R. Milroy, J. Piper // The Computer and Literary Studies / Aitken, A. J., Bailey, R. W. and HamiltonSmith, N. (Eds.). - Edinburgh : University Press. - 1973. - 315 p.

10. Mochida A. Antonymy and Synonymy in Adjectives in L2 Mental Lexicon: Associative or Conceptual relations? [Електронний ресурс] // The University of Queensland, 2003. - www. geocities.jp/akiramochida33/researchpro.html

11. The Dictionary of the Scots Language. [Електронний ресурс] / Caroline Macafee A History of Scots to 1700 // Edinburgh: Scottish Language Dictionaries, 2007. - www.dsl.ac.uk

\title{
МОДЕЛЬ ДІАХРОННОГО СЕМАНТИЧНОГО ДИФЕРЕНЦАТОРА: СТРАТИФІКАЦІЯ ЛЕКСИКИ НА НЕЧІТКИХ ЗАСАДАХ (на матеріалі прикметників давньошотландської мови)
}

\section{Олена Басалкевич}

Львівський національний медичний університет імені Данила Галицького

вул. Пекарська, 69, Львів, Украӥна, 79000

olena.basalkevych@gmail.com

\section{Михайло Білинський}

\author{
Львівський національний університет імені Івана Франка \\ вул. Університетська, 1, Львів, Україна, 79000 \\ 79000 bislo@ukrpost.ua
}

У роботі послідовно розгорнено уніфіковану математичну модель для дослідження синонімії у контексті парадигматичних та епідігматичних асоціативних зв'язків. Сполучені нечіткі асоціативні поля двох антонімів складають з одного боку основний компонент асоціативної карти, активованої фазифікацією у нечітку асоціативну вербальну мережу, в той час як з іншого боку вони представляють нечітку модифікацію семантичного диференціатора Осгуда 3 можливістю діахронної стратифікації лексики. Поєднання значного числа таких компонентів на матеріалі давньошотландських прикметників синонімів формує епізодичну прикметникову асоціативну карту згідно з виділеними Кішем двома фундаментальними зв’язками з подальшою іiі активацією у нечітку асоціативну прикметникову мережу. Якщо ж охопити всю мовну синонімію, подана модель прагнутиме до глобальної нечіткої семантичної мережі як дієвої частки штучного інтелекту.

Ключові слова: давньошотландська мова, нечіткі асоціативні поля, нечітка асоціативна структура слова, асоціативна карта, нечітка асоціативна прикметникова мережа, семантичний диференціатор Осгуда, нечіткий нормалізований діахронний 8-ми інтервальний семантичний диференціатор, нечітка стратифікація, асоціативний тезаурус Кіша, глобальна нечітка семантична мережа. 